\title{
Determinants of severe acute malnutrition among under five children in rural Enebsie Sarmidr District, East Gojjam Zone, North West Ethiopia, 2016
}

\author{
Abate Awoke ${ }^{1 *}$, Mulatu Ayana ${ }^{2}$ and Tenaw Gualu ${ }^{3}$
}

\begin{abstract}
Background: Severe acute malnutrition is one of the major public health problems in developing countries having a devastating effect on the lives of many children under 5 years of age. In Ethiopia, there has been isolated studies conducted on malnutrition with no study attempting to identify the determinants of severe acute malnutrition in the rural district of Enebsie Sarmidr.This study intends to identify the determinants of severe acute malnutrition in rural district located in North West Ethiopia.

Methods: A Community based un matched case -control study was carried on 311 (64 cases and 247 controls) children aged between birth-59 months with their respective mothers or care takers from March 1-30/ 2016. Odds Ratio along with 95\% confidence interval was estimated to identify determinants of severe acute malnutrition using the multivariable logistic regression.

Results: The response rate was $97.8 \%$. Severe acute malnutrition was significantly associated with age groups birth-24 months $(A O R=2.64,95 \% \mathrm{Cl} 1.17-5.95)$, late initiation of breast feeding greater than an hour after birth ( $A O R=4.26,95 \% \mathrm{Cl} 1.74-10.42)$, nonexclusive breast feeding ( $A O R=5.81,95 \% \mathrm{Cl} 1.80-18.79$ ), diarrheal disease in the preceding 2 weeks before SAM (AOR $=7.98,95 \% \mathrm{Cl} 2.57-24.74)$, febrile illnesses preceding 2 weeks before SAM (AOR $=2.8795 \% \mathrm{Cl} 1.13-7.63)$, decreased or maintained mealing of the mother compared to the regular during pregnancy or lactation (AOR $=8.15,95 \% \mathrm{Cl} 3.70-17.98$ ) and birth interval less than 2 years $(A O R=3.34,95 \% \mathrm{Cl} 1.55-7.20)$ after controlling other variables effect.

Conclusion: A child's age, late initiation of breast feeding, nonexclusive breast feeding, diarrheal diseases and febrile illnesses preceding 2 weeks before SAM, decreased or maintained mealing compared to the regular during pregnancy and lactating of the mother and narrow birth interval were identified as determinants of SAM. Therefore, collaborative efforts are needed to improve promotion of better child caring practices specifically, child and maternal feeding practices and prevention and treatment of acute illnesses.
\end{abstract}

Keywords: Determinants, Severe acute malnutrition, Under five children, Rural district, Enebsie Sarmidr , Ethiopia

* Correspondence: abateawoke@yahoo.com

${ }^{1}$ East Gojjam Zone Health Department, Debre Markos, Ethiopia

Full list of author information is available at the end of the article

(c) The Author(s). 2018 Open Access This article is distributed under the terms of the Creative Commons Attribution 4.0 International License (http://creativecommons.org/licenses/by/4.0/), which permits unrestricted use, distribution, and reproduction in any medium, provided you give appropriate credit to the original author(s) and the source, provide a link to the Creative Commons license, and indicate if changes were made. The Creative Commons Public Domain Dedication waiver (http://creativecommons.org/publicdomain/zero/1.0/) applies to the data made available in this article, unless otherwise stated. 


\section{Background}

Malnutrition, globally, is linked directly or indirectly to death or disability. In 2015, wasting related to malnutrition threatened the lives of 50 million children under 5 years of age, globally, of which 3.5 million will succumb [1].

In Africa 14.1.million cases of wasting have been identified with one third or 4.3 million categorized as severe wasting. Eastern Africa has,also, identified 6.6\% of children under 5 years of age as wasted due to malnutrition [2]. Ethiopia has the region's highest rate of wasting, or acute malnutrition with $9 \%$ identified as wasted and $33.3 \%$ severely malnourished [3]. The prevalence of malnutrition ranges from $1.4 \%$ in Addis Ababa to $10 \%$ in Somali with a further distinction of higher prevalence of severe malnourishment. In many health facility, deaths are attributed to malnutrition; one study estimated 57\% [4], and another stated $20 \%$ that further identified severe acute malnourishment as the cause of death $[5,6]$.

Different reasons can be considered for possible risk factors for severe acute malnutrition (SAM) around the world including Ethiopia. However, with the problem higher in developing countries like Ethiopia and the risk factors, may be seasonal or pervasive. Maternal, childhood or family based problems could be a determinant of nutrition and by contrast malnutrition. The variance is then related to the geographical location, the time of year, and the sex of the child [7, 8]. For example, differences are observed by gender and urban-rural residence; wasting affects more boys (11.1\%) compared with girls (8.2\%) and more children in rural areas (10.2\%) compared with urban areas (5.7\%) [6].

Over the 30 years, Ethiopia has been implementing different programs to overcome SAM with little effect as the diagnosis remains high and the prevalence has been increasing. As a result, identifying specific determinants of SAM in children under 5 years of age will assist in directing significant investments to overcome the problem [9].

\section{Objectives}

- To identify determinants of severe acute malnutrition among rural district of children under 5 years of age living in Enebsie Sarmidr district, North West Ethiopia, 2016.

\section{Methods}

\section{Study area and period}

The study was conducted in the rural district of Enebsie Sarmidr, East Gojjam Zone, North West Ethiopia from March 1-30/2016. Enebsie Sarmidr district is located in East Gojjam Zone which is $364 \mathrm{~km}(\mathrm{~km})$ far from Addis Ababa the capital city of Ethiopia, $182 \mathrm{~km}$ far from Bahir Dar the capital town of Amhara region and $194 \mathrm{~km}$ away from Debre Markos the capital town of East Gojjam
Zone. The district has one district public hospital, seven public health centers, two medium private clinics and two urban and 31 rural health posts. Six health centers has stabilizing centers for complicated SAM cases management. The study area selection was done after review of the district's annual report, as well there was paucity of research on SAM in this district.

\section{Study design}

A community based unmatched case control study design was employed to identify the risk factors of severe acute malnutrition among children under 5 years of age. Unmatched case control study was used because the number of the cases were small when compared to the number of controls. This study design was taken to determine the risk factors of SAM at the single point, case identification, followed by data collection.

\section{Source population}

Dyads defined as all mothers to children under 5 years of age living in rural district of Enebsie Sarmidr in a 1 month period in 2016.

\section{Study population}

Randomly selected cases and controls of Dyads who fulfill the inclusion criteria.

\section{Inclusion criteria}

Dyads who lived at least 6 months in the study area.

\section{Exclusion criteria}

Mothers unable to communicate due to illness or in voluntarism and controls from the same house of cases.

\section{Sample size}

The sample size was calculated using Epi info 7 statcalc. The assumptions used for calculation were detecting a 3.5 times higher risk of suboptimal infant breast feeding practices among the cases and a 65.9 prevalence of suboptimal infant breast feeding practice among the controls based on the study done previously; $95 \%$ confidence interval (CI), 90\% power and case to control ratio of 1:4 [7]. The case control ratio of 1: 4 was used to increase the power and sample size. As the number of cases were small, the sample size was increased by increasing the number of the controls. This made the minimum calculated sample size 58 for cases and 231 for controls. By taking 10\% nonresponse rate the total sample size required was 318 having 64 cases and 254 controls.

\section{Sampling procedure}

The district has 31 rural kebeles. All the 31 kebeles were included in the study. For this study, survey was conducted before the actual study and there were 13,122 
under five children in the district. Of these, 115 were found with SAM. So the calculated sample size, 64 cases and 254 controls were selected in proportional allocation to the sample size of each of the 31 rural kebeles using computer generated simple random sampling technique in 1:4 case, control ratio. Totally 318 mother/care giver to child pairs were included.

Variables

Dependent variables

- Severe acute malnutrition.

\section{Independent variables}

- Socio demographic characteristics; age of child, child sex, parental education, parental occupation, marital status of the mother, household economic status, maternal autonomy in decision making and family size

- Nutrition and Child caring practices; Exclusive breast feeding (EBF), Sub optimal EBF, late initiation of breast feeding.

- Infection and childhood illness: Fever, Human immune deficiency virus (HIV), diarrhea, other medical and surgical problems.

- Obstetric History: Antenatal care (ANC) visits, number of ANC visit, birth order, birth interval, use of extra food during pregnancy and lactation, number of children ever born.

\section{Operational definitions}

\section{Cases}

"Dyads defined as all mothers to children under 5 years of age with SAM treated in an outpatient or inpatient therapeutic program in rural district of Enebsie Sarmidr in a 1 month period in 2016 .

\section{Controls}

"Dyads defined as all mothers to children under 5 years of age with no diagnosis of severe acute malnutrition in rural district of Enebsie Sarmidr in a 1 month period in 2016 .

\section{Diarrhea}

Unusual frequent and loose watery stool $\geq 3$ times per day for 2 weeks or more.

\section{Fever}

Mothers/care takers thought as the child experienced unusual increase in temperature for 2 weeks or more.

\section{Sub optimal exclusive breast feeding}

Breast feeding less than eight times per day.

\section{Household economic status}

Monthly income of the family in Ethiopian Birr.

\section{Maternal autonomy in decision making}

Perceived maternal autonomy in decision making within the family.

\section{Low income}

Household monthly income less than 1000 Ethiopian Birr.

\section{Instrument and personnel}

Interviewers followed semi structured questionnaires that were created from published research on the study area $[4,6,8,10]$. Data collectors were three clinical nurses who took training on nutrition courses. Two clinicians supervised the data collection process. Two days of training was provided by the principal investigators to the data collectors \& supervisors.

\section{Data quality control}

Before data collection the questionnaire was first prepared in English and translated to the local language Amharic and finally again back to English for consistency. The questionnaire was pre tested on $5 \%$ of actual respondents in another kebele out of the study area. During the data collection time, regular monitoring and supervision of the overall activity was done by the supervisors and principal investigators to ensure the quality of data. All the collected data were checked, cleaned and coded to avoid some inconsistencies and incompleteness before analysis. Incomplete and inconsistent data were excluded from the analysis.

\section{Data processing and analysis}

The data was cleaned, coded and entered in Epi data version 3.1 and transferred to statistical package for Social science (SPSS) version 20.0 for analysis. Emergency nutrition assessment (ENA) software was used to calculate anthropometric measurements. Both bivariate and multivariate logistic regressions were used to determine the association. Variables with $(P<0.2)$ in the bivariate logistic regression was included in the final model/multivariable. Statistical significance was made at $95 \% \mathrm{CI}$ and $P$-value $<0.05$ for multivariate analysis. The strength of association between independent and dependent variables was assessed using odds ratio with 95\% confidence interval.

\section{Ethical issues}

Ethical clearance was obtained from research and publication committee of Debre Markos University, College of Health Sciences. Informed written consent was obtained from the mothers. 


\section{Results}

The response rate was $97.8 \%$ (64 cases and 247 controls). The median age of the child in the Dyad, both cases and controls, was 18 months with standard deviation (SD) of 10.38 and 14.02 months respectively. The majority $(71.9 \%)$ of children in the cases and more than half $(56.3 \%)$ of the controls were between 7 and 24 months (Table 1 ).

About (87.5\%) of the cases and (97.2\%) of the controls were born from mothers who had ANC follow up. There was similar equivalency $(53.1 \%$ cases to $58.3 \%$ ) of mothers who were seen $1-3$ times in ANC follow up (Table 2).

Approximately two-thirds (70.3\%) of the cases and almost all (91.1\%) of the controls had initiated breast feeding within an hour of birth. A similar statistical difference $(78.1 \%$ of the cases compared to $96.8 \%$ of the controls) was found related to exclusive breast feeding for the 6 months of life (Table 3).

\section{Determinants of severe acute malnutrition}

Variables that showed an association with the outcome variable at $P$ value $(P<0.2)$ in the bivariable analysis were entered into the final multivariable analysis. Odds ratio along with $95 \%$ confidence interval was estimated to assess the strength of the association and $\mathrm{P}$ value < 0.05 was used to declare the statistical significance in the multivariable analysis.

Sociodemographic determinants; age group below 2 years [Crude odds ratio $(\mathrm{COR})=1.683,95 \% \mathrm{CI}$, $(0.892-3.178)]$, family size who had 6 and above $(\mathrm{COR}=$ $0.47,95 \%$ CI $(0.26-0.87)$ ), family income who had averagely less than 1000 Ethiopian Birr $(\mathrm{COR}=2.731,95 \% \mathrm{CI}$ (0.621-12.004) had $P$-value less than 0.2 (Table 4).

In multivariate analysis, children's aged between birth to 24 months were 2.6 times more likely to be severely acute malnourished than those children aged between 25 and 59 months [adjusted odds ratio $(\mathrm{AOR})=2.63$, 95\% CI 1.17-5.95]. Mothers who did not initiate breast

Table 1 Sociodemographic characteristics of Mother/care giver with their under five children in rural district of Enebsie Sarmidr, March, $2016(N=311)$

\begin{tabular}{|c|c|c|c|c|}
\hline \multirow[t]{2}{*}{ Variables } & & \multicolumn{2}{|l|}{$\underline{\text { SAM status }}$} & \multirow[t]{2}{*}{ Total N (\%) } \\
\hline & & Cases n (\%) & Control n (\%) & \\
\hline \multirow[t]{4}{*}{ Age of child } & Birth -6 months & $3(4.7 \%)$ & $24(9.7 \%)$ & $27(8.7 \%)$ \\
\hline & 7-24 months & $46(71.9 \%)$ & 139(56.3\%) & $185(59.5 \%)$ \\
\hline & $25-59$ months & $15(23.4 \%)$ & $84(34.0 \%)$ & $99(31.8 \%)$ \\
\hline & Total & $64(100.0 \%)$ & $247(100.0 \%)$ & $311(100.0 \%)$ \\
\hline \multirow[t]{3}{*}{ Sex of children } & Male & $32(50.0 \%)$ & $118(47.8 \%)$ & $150(48.2 \%)$ \\
\hline & Female & $32(50.0 \%)$ & $129(52.2 \%)$ & $161(51.8 \%)$ \\
\hline & Total & $64(100.0 \%)$ & $247(100.0 \%)$ & $311(100.0 \%)$ \\
\hline \multirow[t]{3}{*}{ Family size } & $\leq 5$ family members & $22(34.4 \%)$ & $130(52.6 \%)$ & 152(48.9\%) \\
\hline & $\geq 6$ family members & $42(65.6 \%)$ & $117(47.4 \%)$ & $159(51.1 \%)$ \\
\hline & Total & $64(100.0 \%)$ & $247(100.0 \%)$ & $311(100.0 \%)$ \\
\hline \multirow[t]{4}{*}{ Family average income ETB } & $\leq 500$ & $48(75.0 \%)$ & $167(67.6 \%)$ & $215(69.1 \%)$ \\
\hline & (500-999] & $14(21.9 \%)$ & $60(24.3 \%)$ & $74(23.8 \%)$ \\
\hline & $\geq 1000$ & $2(3.1 \%)$ & $20(8.1 \%)$ & $22(7.1 \%)$ \\
\hline & Total & $64(100.0 \%)$ & $247(100.0 \%)$ & $311(100.0 \%)$ \\
\hline \multirow[t]{4}{*}{ The authority of decision making in the family } & Mother & $4(6.2 \%)$ & 19(7.7\%) & $23(7.4 \%)$ \\
\hline & Father & $22(34.4 \%)$ & $89(36.0 \%)$ & $111(35.7 \%)$ \\
\hline & Both father \& mother & $38(59.4 \%)$ & $139(56.3 \%)$ & $177(56.9 \%)$ \\
\hline & Total & $64(100.0 \%)$ & $247(100.0 \%)$ & $311(100.0 \%)$ \\
\hline \multirow[t]{3}{*}{ Respondents'/ Care givers' religion } & Orthodox & $59(92.2 \%)$ & 238(96.4\%) & 297(95.5\%) \\
\hline & Muslim & $5(7.8 \%)$ & $9(3.6 \%)$ & $14(4.5 \%)$ \\
\hline & Total & $64(100.0 \%)$ & $247(100.0 \%)$ & $311(100.0 \%)$ \\
\hline \multirow[t]{3}{*}{ Marital status } & Married \& Lives with husband & $57(89.1 \%)$ & $221(89.5 \%)$ & 278(89.4\%) \\
\hline & Lives without husband & $7(10.9 \%)$ & $26(10.5 \%)$ & $33(10.6 \%)$ \\
\hline & Total & $64(100.0)$ & $247(100.0)$ & $311(100.0)$ \\
\hline
\end{tabular}


Table 2 Obstetric history of mothers/care taker with their under five children and SAM status at rural district of Enebsie Sarmidr March, $2016(N=311)$

\begin{tabular}{|c|c|c|c|c|}
\hline \multirow[t]{2}{*}{ Variables } & & \multicolumn{2}{|l|}{ SAM status } & \multirow[t]{2}{*}{ Total N (\%) } \\
\hline & & Cases n (\%) & Controls n (\%) & \\
\hline \multirow[t]{4}{*}{ Number of children ever borne } & $\geq 4$ Children & $20(31.3 \%)$ & $83(33.6 \%)$ & 103(33.1\%) \\
\hline & 1-3 children & $41(64.1 \%)$ & $162(65.6 \%)$ & $203(65.3 \%)$ \\
\hline & I do not remember & $3(4.7 \%)$ & $2(0.8 \%)$ & $5(1.6 \%)$ \\
\hline & Total & $64(100.0 \%)$ & $247(100.0 \%)$ & $311(100.0 \%)$ \\
\hline \multirow[t]{3}{*}{ ANC follow up } & Yes & $56(87.5 \%)$ & $240(97.2 \%)$ & 296(95.2\%) \\
\hline & No & $8(12.5 \%)$ & $7(2.8 \%)$ & $15(4.8 \%)$ \\
\hline & Total & $64(100.0 \%)$ & $247(100.0 \%)$ & $311(100.0 \%)$ \\
\hline \multirow[t]{4}{*}{ Number of ANC follow up } & $\geq 4$ times & $27(42.2 \%)$ & $90(36.4 \%)$ & $117(37.6 \%)$ \\
\hline & $1-3$ times & $34(53.1 \%)$ & $144(58.3 \%)$ & 178(57.2\%) \\
\hline & I do not remember & $3(4.7 \%)$ & $13(5.3 \%)$ & $16(5.1 \%)$ \\
\hline & Total & $64(100.0 \%)$ & $247(100.0 \%)$ & $311(100.0 \%)$ \\
\hline \multirow{3}{*}{$\begin{array}{l}\text { Feeding status during pregnancy and } \\
\text { lactating }\end{array}$} & extra meal/day & $37(57.8 \%)$ & 225(91.1\%) & $262(84.2 \%)$ \\
\hline & No difference/reduced my meal & $27(42.2 \%)$ & $22(8.9 \%)$ & 49(15.8\%) \\
\hline & Total & $64(100.0 \%)$ & $247(100.0 \%)$ & $311(100.0 \%)$ \\
\hline \multirow[t]{3}{*}{ Reason for increasing feeding } & Health workers thought and clear & $37(100.0 \%)$ & $221(98.2 \%)$ & 259(98.5\%) \\
\hline & Any other reason & $0(0.0 \%)$ & $4(1.8 \%)$ & $4(1.5 \%)$ \\
\hline & Total & $37(100.0 \%)$ & $225(100.0 \%)$ & $262(100.0 \%)$ \\
\hline \multirow{4}{*}{$\begin{array}{l}\text { Reasons for decreasing feeding during } \\
\text { pregnancy }\end{array}$} & Believing not be comfortable for fetus & $24(88.9 \%)$ & $16(72.7 \%)$ & $40(81.6 \%)$ \\
\hline & $\begin{array}{l}\text { Believing fetal growth would be facilitated and delivery } \\
\text { complicated }\end{array}$ & $2(7.4 \%)$ & $5(22.7 \%)$ & $7(14.3 \%)$ \\
\hline & Others & $1(3.7 \%)$ & $1(4.5 \%)$ & $2(4.1 \%)$ \\
\hline & Total & $27(100.0 \%)$ & $22(100.0 \%)$ & $49(100.0 \%)$ \\
\hline \multirow[t]{3}{*}{ Birth interval } & Less than 2 years & $24(37.5 \%)$ & $52(21.1 \%)$ & $76(24.4 \%)$ \\
\hline & 2 and above years & $40(62.5 \%)$ & 195(78.9\%) & 235(75.6\%) \\
\hline & Total & $64(100.0 \%)$ & $247(100.0 \%)$ & $311(100.0 \%)$ \\
\hline
\end{tabular}

feeding within $1 \mathrm{~h}$ after delivery were more than 4 times more likely to have severely acute malnourished child than mothers' who initiated to fed their breast within 1 $\mathrm{h}$ after delivery $(\mathrm{AOR}=4.25,95 \%$ CI $1.74-10.41)$. Likewise children who were not fed breast milk exclusively for their first 6 months of age were 5.8 times more likely to develop severe acute malnutrition than those who were fed exclusively (AOR $=5.81,95 \%$ CI 1.79-18.78).

Severe wasting was 7.9 times more likely to occur in children who had diarrhea within 2 weeks before developing SAM than those children who did not have diarrhea within 2 weeks before developing SAM (AOR $=7.97$, 95\% CI 2.57-24.73. Likewise severe acute malnutrition was 2.8 times more likely to occur in children who had febrile illness within 2 weeks before developing SAM than those children who did not have febrile illness within 2 weeks before developing SAM (AOR = 2.87 95\% CI 1.13-7.62).

Similarly children who were born from mothers who didn't change their feeding status from the regular level during pregnancy and lactation were 8 times more likely to be severely acute malnourished than those who were born from mothers who had increased at least one extra meal per day during pregnancy and lactation (AOR $=8.15,95 \%$ CI 3.69-17.97). Similarly children who were born from mothers with birth interval of less than 2 years were more than 3 times highly exposed to severe acute malnutrition than those who were born from mothers who had $\geq 2$ years of birth interval $(\mathrm{AOR}=3.33$, 95\% CI 1.547.19) (Table 5).

\section{Discussion}

In this study, children's age group of birth-24 months showed significant association with severe acute malnutrition. The result is similar to studies done in Ethiopia, India, Katranaka $[11,12]$.

Those who are in age groups ( $\leq 24$ months) were three times more likely to develop SAM than their counter parts. This might from because the first 2 years of life are extremely important for the growth and development of 
Table 3 Child nutrition and care practices of under five children and their SAM status at rural district of Enebsie Sarmidr district, March, 2016, $(N=311)$

\begin{tabular}{|c|c|c|c|c|}
\hline \multirow[t]{2}{*}{ Variables } & & \multicolumn{2}{|l|}{ SAM status } & \multirow[t]{2}{*}{ Total N (\%) } \\
\hline & & Cases n (\%) & Controls n (\%) & \\
\hline \multirow[t]{3}{*}{ Breast feeding (BF) Initiation within an hour after delivery } & Yes & $45(70.3 \%)$ & $225(91.1 \%)$ & $270(86.8 \%)$ \\
\hline & No & 19(29.7\%) & $22(8.9 \%)$ & $41(13.2 \%)$ \\
\hline & Total & $64(100.0 \%)$ & $247(100.0 \%)$ & $311(100.0 \%)$ \\
\hline \multirow[t]{3}{*}{ EBF for the first 6 months } & Yes & $50(78.1 \%)$ & 239(96.8\%) & 289(92.9\%) \\
\hline & No & $14(21.9 \%)$ & $8(3.2 \%)$ & $22(7.1 \%)$ \\
\hline & Total & $64(100.0 \%)$ & $247(100.0 \%)$ & $311(100.0 \%)$ \\
\hline \multirow[t]{3}{*}{ Optimum breast feeding( $\geq 8$ times/day) } & Yes & $28(43.8 \%)$ & $231(93.5 \%)$ & 259(83.3\%) \\
\hline & No & $36(56.2 \%)$ & $16(6.5 \%)$ & $52(16.7 \%)$ \\
\hline & Total & $64(100.0 \%)$ & $247(100.0 \%)$ & $311(100.0 \%)$ \\
\hline \multirow[t]{3}{*}{ Total time of breast feeding } & 1-24 months & $5(7.8 \%)$ & $17(6.9 \%)$ & $22(7.1 \%)$ \\
\hline & $\geq 25$ months & $59(92.2 \%)$ & 230(93.1\%) & 289(92.9\%) \\
\hline & Total & $64(100.0 \%)$ & $247(100.0 \%)$ & $311(100.0 \%)$ \\
\hline \multirow[t]{3}{*}{ History of prelacteal feeding } & Yes & $13(20.3 \%)$ & $21(8.5 \%)$ & $34(10.9 \%)$ \\
\hline & No & $51(79.7 \%)$ & $226(91.5 \%)$ & $277(89.1 \%)$ \\
\hline & Total & $64(100.0 \%)$ & $247(100.0 \%)$ & $311(100.0 \%)$ \\
\hline
\end{tabular}

Table 4 Bivariable analysis of determinants of SAM on under five children at rural kebeles of Enebsie Sarmidr district, March, 2016, $(N=311)$

\begin{tabular}{|c|c|c|c|c|c|}
\hline \multirow[t]{2}{*}{ Variables } & & \multicolumn{2}{|l|}{ SAM status } & \multirow[t]{2}{*}{$\operatorname{COR}(95 \%, \mathrm{Cl})$} & \multirow[t]{2}{*}{$P$-value } \\
\hline & & Cases n (\%) & Controls n (\%) & & \\
\hline \multirow[t]{2}{*}{ Age } & 0-24 months & 49(76.6\%) & $163(66 \%)$ & $1.68(0.89-3.17)$ & 0.108 \\
\hline & 25-59 months & 15(23.4\%) & 84(34\%) & 1 & \\
\hline \multirow[t]{2}{*}{ Family size } & $<6$ & $22(34.4 \%)$ & $130(52.6 \%)$ & 1 & \\
\hline & $\geq 6$ & $42(65.6 \%)$ & $117(47.4 \%)$ & $0.47(0.26-0.87)$ & 0.10 \\
\hline \multirow[t]{2}{*}{ Family income } & $<1000$ EBR & $62(96.9 \%)$ & 227(92\%) & $2.73(0.62-12.00)$ & 0.183 \\
\hline & $\geq 1000$ EBR & $2(3.1 \%)$ & $20(8 \%)$ & 1 & \\
\hline \multirow[t]{2}{*}{ Prelacteal feeding } & Yes & 13(20.3\%) & $21(8.5 \%)$ & $2.74(1.28-5.83)$ & 0.009 \\
\hline & No & $51(79.7 \%)$ & $226(91.5 \%)$ & 1 & \\
\hline \multirow[t]{2}{*}{ Exclusive BF } & Yes & $50(78.1 \%)$ & 239(96.8\%) & 1 & \\
\hline & No & $14(21.9 \%)$ & $8((3.2 \%)$ & $8.36(3.33-21.00)$ & 0.001 \\
\hline \multirow[t]{2}{*}{ BF initiation within one hr. after delivery } & Yes & $45(70.3 \%)$ & 225(91.1\%) & 1 & \\
\hline & No & $19(29.7 \%)$ & $22(8.9 \%)$ & $4.318(2.16-8-62)$ & 0.001 \\
\hline \multirow{2}{*}{$\begin{array}{l}\text { Diarrhea in the preceding } 2 \text { weeks before developing } \\
\text { SAM }\end{array}$} & Yes & $14(21.9 \%)$ & $9(3.6 \%)$ & $7.40(3.03-18.05)$ & 0.001 \\
\hline & No & $50(78.1 \%)$ & $238(96.4 \%)$ & 1 & \\
\hline \multirow{2}{*}{$\begin{array}{l}\text { Febrile illness in the preceding } 2 \text { weeks before } \\
\text { developing SAM }\end{array}$} & Yes & $13(20.3 \%)$ & $20(8.1 \%)$ & $2.89(1.351-6.19)$ & 0.006 \\
\hline & No & $51(79.7 \%)$ & $227(91.9 \%)$ & 1 & \\
\hline \multirow[t]{2}{*}{ Having ANC follow up } & Yes & $56(87.5 \%)$ & $240(97.2 \%)$ & 1 & \\
\hline & No & $8(12.5 \%)$ & $7(2.8 \%)$ & $4.89(1.70-14.07)$ & 0.003 \\
\hline \multirow[t]{2}{*}{ Feeding status during pregnancy } & I ate least one extra mealing & $37(57.8 \%)$ & 225(91.1\%) & 1 & \\
\hline & $\begin{array}{l}\text { Did not increase or decreased } \\
\text { mealing }\end{array}$ & $27(42.2 \%)$ & $22(8.9 \%)$ & 7.46(3.851-14.46) & 0.001 \\
\hline \multirow[t]{2}{*}{ Birth interval } & $<2$ years & $24(37.5 \%)$ & $52(21.1 \%)$ & $2.25(1.24-4.06)$ & 0.007 \\
\hline & $>=2$ years & $40(62.5 \%)$ & 195(78.9\%) & 1 & \\
\hline
\end{tabular}


Table 5 Multivariable analysis of determinants of SAM among under five children at rural kebeles of Enebsie Sarmidr district, March, 2016, $(N=311)$

\begin{tabular}{|c|c|c|c|c|c|}
\hline \multirow[t]{2}{*}{ Variables } & & \multicolumn{2}{|c|}{ Nutritional status } & \multirow[t]{2}{*}{ AOR $(95 \% \mathrm{Cl})$} & \multirow[t]{2}{*}{$P$-value } \\
\hline & & Cases n (\%) & Controls n (\%) & & \\
\hline \multirow[t]{2}{*}{$\overline{\text { Age }}$} & Birth -24 months & $49(76.6 \%)$ & $163(66 \%)$ & $2.637(1.1691-5.950)$ & 0.019 \\
\hline & 25-59 months & $15(23.4 \%)$ & $84(34 \%)$ & 1 & \\
\hline \multirow[t]{2}{*}{ BF initiation within one hr. After delivery } & Yes & $45(70.3 \%)$ & 225(91.1\%) & 1 & \\
\hline & No & 19(29.7\%) & $22(8.9 \%)$ & $4.257(1.740-10.416)$ & 0.002 \\
\hline \multirow[t]{2}{*}{ Exclusive breast feeing } & Yes & $50(78.1 \%)$ & 239(96.8\%) & 1 & \\
\hline & No & 14(21.9\%) & $8((3.2 \%)$ & $5.812(1.798-18.781)$ & 0.003 \\
\hline \multirow{2}{*}{$\begin{array}{l}\text { Febrile illness preceding } 2 \text { weeks before } \\
\text { developing SAM }\end{array}$} & Yes & $13(20.3 \%)$ & $20(8.1 \%)$ & $2.870(1.133-7.628)$ & 0.026 \\
\hline & No & $51(79.7 \%)$ & 227(91.9\%) & 1 & \\
\hline \multirow{2}{*}{$\begin{array}{l}\text { Diarrhea preceding } 2 \text { weeks before developing } \\
\text { SAM }\end{array}$} & Yes & $14(21.9 \%)$ & $9(3.6 \%)$ & $7.977(2.572-24.739)$ & 0.001 \\
\hline & No & $50(78.1 \%)$ & 238(96.4\%) & 1 & \\
\hline \multirow[t]{2}{*}{ Feeding practice during pregnancy } & Increased at least one additional & $37(57.8 \%)$ & 225(91.1\%) & 1 & \\
\hline & $\begin{array}{l}\text { Remained as regular/decreased from } \\
\text { the regular }\end{array}$ & $27(42.8 \%)$ & $22(8.9 \%)$ & $8.151(3.696-17.976)$ & 0.001 \\
\hline \multirow[t]{2}{*}{ Birth interval } & $<2$ years & $24(37.5 \%)$ & $52(21.1 \%)$ & $3.337(1.547-7.199)$ & 0.002 \\
\hline & $\geq 2$ years & $40(62.5 \%)$ & 195(78.9\%) & 1 & \\
\hline
\end{tabular}

children. And it is a time for most malnutrition cases to occur because it is a transition time from exclusive breast feeding to complementary feeding.

Maternal initiation of breast feeding after $1 \mathrm{~h}$ of delivery was significantly associated with severe acute malnutrition. Children who were breast fed within the first hour after birth were four times more likely to develop severe acute malnutrition when compared to those who initiated breast feeding within an hour of birth. The result is in line with a study done in Kenya where non-exclusive breast feeding was significantly associated with severe acute malnutrition and wasting. Babies not exclusively breast fed in the Kenya study were 6 times more likely to develop wasting and severe acute malnutrition [10]. Additional studies supported by the result from this study [5, 6, 8, 13]. This fact, that breast milk contains everything the baby wants for the first 6 months of life and exclusive breast feeding, supports the role of breast milk in assisting the infant fight infections including diarrheal diseases which may later result in malnutrition.

Diarrhea within 2 weeks before the onset of SAM was significantly associated with severe acute malnutrition. Those children who had diarrheal diseases were eight times more likely to develop SAM when compared to their counterparts. Similar findings were found in the studies done in Bhandari hospital, Mongo district, EDHS report and Felege Hiwot [4, 9, $11,14]$. This might from the fact that diarrheal diseases may result in loss of body fluids and electrolyte and nutritional imbalance.
Similarly febrile illness within 2 weeks before the onset of SAM was significantly associated with severe acute malnutrition. Those who had febrile illness within 2 weeks before SAM were three times more likely to develop SAM than those who hadn't febrile illness. The result is in line with other findings $[8,10]$.

Children who were born from mothers with narrow birth interval $(<2$ years) were three times more likely to develop severe acute malnutrition. The result is similar with the studies done in East Ethiopia [7, 10, 13, 15]. This might from the fact that decreased birth interval increases the number of children which may in turn affect child feeding practice.

Children who were born from mothers who didn't increase feeding during pregnancy and/or lactation were eight times more likely to develop SAM than others. The result is not in congruent with a study done at Dollo Ado where the risk of being wasted was 1.55 times higher among mother of children who consumed extra food during pregnancy than previous [16]. This might from the fact that the fetus during pregnancy and the infant afterwards acquires its nutrition from the mother as a result mothers need extra food during pregnancy and breast feeding.

\section{Conclusions}

Age of the child, initiation of breast feeding $1 \mathrm{~h}$ after delivery, nonexclusive breast feeding, diarrheal disease and febrile illnesses within 2 weeks before SAM, decreased or no change of mealing compared to the regular during pregnancy and lactating of the mother and narrow birth interval were determinants of SAM. 
As a result, collaborative efforts should be organized to improve promotion of better child caring practices through appropriate age specific child and maternal feeding practices, prevention and early treatment of acute childhood illnesses and promotion of birth spacing through family planning.

\section{Abbreviations}

ANC: Ante natal care; AOR: Adjusted odds ratio; BF: Breast feeding; $\mathrm{Cl}$ : Confidence interval; COR: Crude odds ratio; EBF: Exclusive breast feeding; EDHS: Ethiopia demographic and health survey; HIV: Human immune deficiency virus; Km: Kilometer; SAM: Sever acute malnutrition; SD: Standard deviation; SPSS: Statistical package for social science

\section{Acknowledgements}

Our gratitude extends to Debre Markos University, Enebsie Sarmidr district health office, data collectors and study participants.

\section{Funding}

Not applicable.

\section{Availability of data and materials}

Not applicable due to confidentiality of information.

\section{Authors' contributions}

AA coded, cleaned, entered and analyzed the data. MA interpreted and reviewed the data and TG wrote the report and prepared the manuscript. All authors have read and approved of the final manuscript.

\section{Ethics approval and consent to participate}

Ethical clearance was obtained by the Ethical review committee of college of Health Sciences, Debre Markos University. Permission to conduct the study was also obtained from East Gojjam zone health department and Enebsie Sarmidr Woreda health office. Informed consent was obtained from each study participant. Study participants were informed that all the data obtained from them were kept confidential by using codes instead of any personal identifiers and was meant only for the purpose of the study.

\section{Consent for publication}

Not applicable.

\section{Competing interests}

The authors declare that they have no competing interests.

\section{Publisher's Note}

Springer Nature remains neutral with regard to jurisdictional claims in published maps and institutional affiliations.

\section{Author details}

'East Gojjam Zone Health Department, Debre Markos, Ethiopia. ${ }^{2}$ Department of Public Health, College of Health Sciences, Debre Markos University, Debre Markos, Ethiopia. ${ }^{3}$ Department of Nursing, College of Health Sciences, Debre Markos University, P.O.BOX: 269, Debre Markos, Ethiopia.

Received: 15 December 2016 Accepted: 31 January 2018 Published online: 09 February 2018

\section{References}

1. Hobbs B, Bush A, Shaikh B, Azmat S, Mazhar A, Solter S, et al. Acute malnutrition: an everyday emergency. A 10-point plan for tackling acute malnutrition in under-fives. JPMA J Pak Med Assoc. 2013;63(4 Suppl 3):S67-72.

2. UNICEF. Levels and trends in child malnutrition UNICEF-WHO-World Bank Group joint child malnutrition estimates. 2015

3. ICF International. Children's health and nutritional status: data from the 2011 Ethiopia demographic and health survey. Calverton, Maryland, USA: ICF International; 2012.

4. Bleyere MN, Kokore BA, Konan AB, Yapo PA. Prevalence of child malnutrition through their anthropometric indices in school canteens of Abidjan (Côte D'ivoire). Pak J Nutr. 2013;12(1):60-70.
5. Case pc. Evaluation of community management of acute malnutrition (cmam). 2012.

6. Demographic E. Health survey 2011 central statistical agency Addis Ababa. Maryland, USA: Ethiopia ICF International Calverton; 2012

7. Dereje N. Determinants of severe acute malnutrition among under five children in Shashogo Woreda, southern Ethiopia: a community based matched case control study. International Journal of Research. 2014;1(6):339-63.

8. Ratnayake R, Tesfai C, Myatt M. Determining predictors for severe acute malnutrition: causal analysis within a SQUEAC assessment in Chad. Field Exchange. 2013;45:23-5

9. GotFDR E. National Nutrition Programme June 2013-June 2015. Addis Ababa: Government of Federal Democratic Republic of Ethiopia; 2013.

10. Mwangome MK, Fegan G, Prentice AM, Berkley JA. Are diagnostic criteria for acute malnutrition affected by hydration status in hospitalized children? A repeated measures study. Nutr J. 2011;10(1):92

11. UNICEF. Evaluation of community management of acute malnutrition CMAM: Ethiopia country case study. New York: UNICEF; 2012.

12. Demographic E. Health survey 2014 central statistical agency Addis Ababa.

13. Egata $G$, Berhane $Y$, Worku A. Predictors of acute undernutrition among children aged 6 to 36 months in east rural Ethiopia: a community based nested case-control study. BMC Pediatr. 2014;14(1):91.

14. Desyibelew HD, Fekadu A, Woldie H. Recovery rate and associated factors of children age 6 to 59 months admitted with severe acute malnutrition at inpatient unit of Bahir Dar Felege Hiwot referral hospital therapeutic feeding unite, northwest Ethiopia. PLoS One. 2017;12(2):e0171020.

15. Aprameya H, Kamath SP, Kini PK, Baliga B, Shenoy U, Jain A, et al. Socioepidemiological determinants of severe acute malnutrition and effectiveness of nutritional rehabilitation center in its management International Journal of Health \& Allied Sciences. 2015;4(3):148.

16. Demissie S, Worku A. Magnitude and factors associated with malnutrition in children 6-59 months of age in pastoral community of Dollo Ado District, Somali region, Ethiopia. Sci J Public Health. 2013;1(4):175-83.

Submit your next manuscript to BioMed Central and we will help you at every step:

- We accept pre-submission inquiries

- Our selector tool helps you to find the most relevant journal

- We provide round the clock customer support

- Convenient online submission

- Thorough peer review

- Inclusion in PubMed and all major indexing services

- Maximum visibility for your research

Submit your manuscript at www.biomedcentral.com/submit
Biomed Central 